This is the peer reviewed version of the following article: T. E. Campano, I. Iriarte, O. Olaizola, J. Etxabe, A. Mielgo, I. Ganboa, J. M.

Odriozola, J. M. García, M. Oiarbide, C. Palomo, Chem. Eur. J. 2019, 25, 4390, which has been published in final form at https:// doi.org/10.1002/chem.201805542. This article may be used for non-commercial purposes in accordance with Wiley Terms and Conditions for Use of Self-Archived Versions

WILEY-VCH

\title{
Enantioselective Addition of Alkynyl Ketones to Nitroolefins Assisted by Brønsted Base/H-Bonding Catalysis
}

\author{
Teresa E. Campano, ${ }^{[a]}$ Igor Iriarte, ${ }^{[a]}$ Olatz Olaizola, ${ }^{[a]}$ Julen Etxabe, ${ }^{[a]}$ Antonia Mielgo, ${ }^{[a]}$ Iñaki Ganboa, ${ }^{[a]}$ \\ José M. Odriozola, ${ }^{[b]}$ Jesús M. García, ${ }^{[b]}$ Mikel Oiarbide ${ }^{*[a]}$ and Claudio Palomo*[a]
}

\begin{abstract}
Various sets of enolizable alkynyl ketones (including methyl ynones $w$ ith $\alpha$-aryl, $\alpha$-alkenyl and $\alpha$-alkoxy groups) are able to react smoothly with nitroolefins under the assistance of bifunctional Brønsted base/ $\mathrm{H}$-bond catalysts to provide adducts $\mathrm{w}$ ith two consecutive tertiary stereocenters in a highly diastereo- and enantioselective fashion. Further transformation of the obtained adducts into optically active acyclic and polycyclic molecules, including some w ith intricate carbon skeletons, is also demonstrated.
\end{abstract}

\section{Introduction}

Given the rich chemistry of both the carbon-carbon triple bond ${ }^{[1]}$ and the carbonyl function, ${ }^{[2]}$ alkynyl ketones ( $\alpha, \beta$-ynones) are excellent building-blocks for organic synthesis. ${ }^{[3]}$ Therefore, the development of catalytic methods for the proliferation of simple ynones through new $\mathrm{C}-\mathrm{C}$ bond forming processes into configurationally defined, structurally and functionally more complex, ynone molecules is highly desirable. One logical approach would rely on the $\alpha$-functionalization of enolizable ynones $w$ ith electrophiles, but the implementation of catalytic asymmetric methodologies progresses very slowly. One problem relies on the tendency of $\alpha, \beta$-ynones to act as Michael acceptors rather than donors. ${ }^{[4]}$ In addition, useful methods w ould require exquisite control of the intervening ketone enolate geometry as well as the stereochemistry of the subsequent $\mathrm{C}-\mathrm{C}$ bond forming reaction. Some direct asymmetric aldol ${ }^{[5]}$ and Mannich ${ }^{[6]}$ reactions of enolizable ynones acting as donor components promoted by bifunctional metal catalysts ${ }^{[5 a-e, 6]}$ or enamine activation ${ }^{[5 f-h]}$ are known. In some instances, the enamine activation approach cannot stop at the acyclic addition adduct which undergoes intramolecular cyclization, ${ }^{[7]}$ hence exemplifying the tendency of $\alpha, \beta$-ynones to act as Michael acceptors.

As a complement to metal- and aminocatalytic activation strategies, Brønsted base catalysis bears great interest considering it proceeds under proton transfer conditions, with

[a] Prof. C. Palomo, Prof. M. Oiarbide, Prof. I. Ganboa, Prof. A. Mielgo, T. E. Campano, I. Iriarte, O. Olaizola, Dr. J. Etxabe

Departamento de Química Orgánica I

Univ ersidad del País Vasco UPV/EHU

Manuel Lardizabal 3, 20018 San Sebastián, Spain

E-mail: claudio.palomo@ehu.es

[b] Prof. J. M. García, Prof. J. M. Odriozola

Departamento de Química Aplicada

Institute for Adv anced Materials (INAMAT)

Univ ersidad Pública de Nav arra

31006-Pamplona, Spain

Supporting information for this article is giv en via a link at the end of the document. ideal atom economy and usually broad functional group tolerance. ${ }^{[8]}$ How ever, a general problem $w$ ith this type of activation is the functional pKa barrier of most catalysts that compromises their efficiency with less acidic carbon pronucleophiles. ${ }^{[9]}$ To our know ledge there is a single report on asymmetric Brønsted base-catalyzed $\alpha$-additions of enolizable ynones, by Peng, Wang and Shao (Scheme 1a, top). ${ }^{[10]}$ Ynone substrates bearing an ester group at $\mathrm{C} \alpha$ are used, requiring a final decarboxylation by acid treatment at $110^{\circ} \mathrm{C}$ in toluene.

a) Known: activated ynones leading to a single stereocenter.

$(A G=$ activating group)

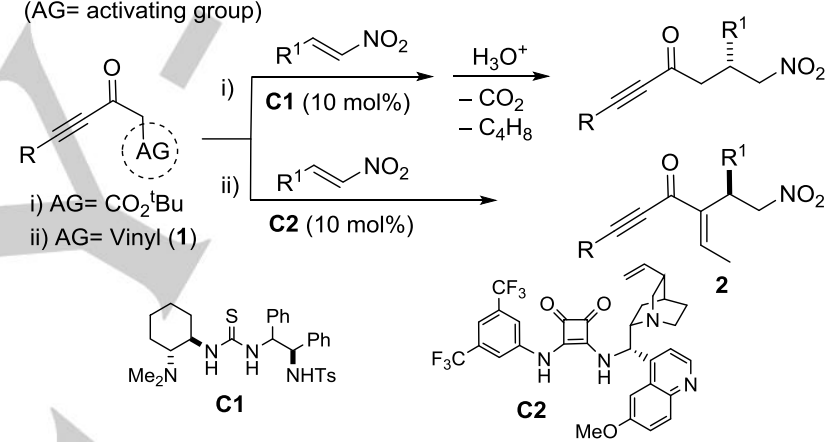

b) This work


$\mathrm{R}^{\prime}$ : Ar, vinyl or alkoxy

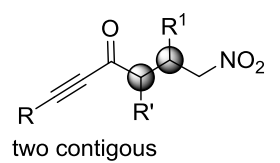

tertiary stereogenic centers
Scheme 1. Progress on bifunctional Brønsted base assisted direct Michae reactions of alky nyl ketones.

During recent studies on the catalyst-controlled reactivity of transiently generated vinylogous ketone enolates, ${ }^{[11]}$ we found that alkynyl allyl ketones are a suitable subset of allyl ketones for their reaction $w$ ith nitroolefins in the presence of bifunctional Brønsted base/H-bond catalysts like $\mathbf{C 2}^{[12]}$ (Scheme 1a down). Interestingly, these reactions proceeded $w$ ith nearly perfect enantio- and $\alpha / \gamma$-selectivity, but, unfortunately, the $\mathrm{C}=\mathrm{C}$ double bond in adducts isomerizes spontaneously to the most stable $\alpha, \beta$ position $w$ ith loss of a stereocenter. ${ }^{[11]}$ Therefore, both the above Brønsted base catalyzed methods afford products $w$ ith a single new stereocenter. In the present investigation we demonstrate that the Brønsted base activation of enolizable $\alpha, \beta$-ynones can be applied beyond the above constrains and thus becomes a practical approach to synthetically useful building-blocks. Specifically, ynones bearing an arylmethyl, alkoxymethyl or $\alpha$ alkenyl sidearm all resulted suitable substrates for direct, 
Brønsted base-catalyzed Michael reactions producing adducts with two contiguous stereogenic centers in high selectivity (Scheme 1b). Details of the substrate scope, catalyst requirements and the utility of thus obtained adducts for accessing stereochemically complex carbon skeletons, are show $n$.

\section{Results and Discussion}

Alkenyl alkynyl ynones. Background and reaction generality. In our preliminary study allyl alkynyl ketones $1 \mathrm{w}$ ere found to react w ith nitroolefins in the presence of catalyst $\mathbf{C 2}$ to afford the MoritaBaylis-Hillmann type products 2. $^{[1]}$ These observations indicate that the initially formed adduct isomerizes spontaneously, with one of the newly created stereocenters being ultimately loosed (Scheme 1a). Our first task was to check whether this isomerization bias is general for other allylic systems. The experiments involving 1,1-(gem)-disubstituted allylic ynone 3A and nitrostyrene $\mathbf{4 a}$ in the presence of several bifunctional Brønsted base catalysts ${ }^{[13]}$ (Scheme 2 and Table 1) show ed that, indeed, the $\beta, \gamma$-unsaturated adduct $5 \mathrm{Aa}$ resists isomerization regardless the catalyst employed. For instance, after $3 \mathrm{~h}$ of stirring at room temperature with 10 mol\% catalyst $\mathbf{C 2}$, adduct $\mathbf{5 A a}$ was obtained in $80 \%$ isolated yield and an excellent $98 \%$ ee, although a nearly equimolar mixture of diastereomers was produced (entry 1). With the $\mathrm{N}$-benzyl analog $\mathbf{C 3}^{[14]}$ diastereoselectivity was improved at the expense of enantioselectivity $(80 \%$ ee, entry 2$)$, $w$ hile the related cyclohexyldiamine-derived squaramide catalyst $\mathbf{C 4}^{[15]}$ afforded product $5 \mathrm{Aa}$ with high ee, but yet suboptimal diastereoselectivity ( $\mathrm{dr} 4: 1,92 \%$ ee, entry 3 ).. After additional screening that show ed thiourea catalysts inferior in reactivity and selectivity (e.g. C5, entry 4), we finally found that the reaction in the presence of new ly developed catalyst $\mathbf{C 6}^{[16]}$ afforded the desired product $\mathbf{5 A a}$ in $82 \%$ yield, a remarkable $19: 1$ dr and $94 \%$ ee (entry 5 ). While the superior behavior of catalyst $\mathbf{C} \mathbf{6}$ correlates w ell with previous observations, ${ }^{[16]}$ it seems that its origin cannot be explained by steric congestion merely as the bulky neopentylderived catalyst $\mathbf{C} 7$ w as comparatively inferior (entry 6).

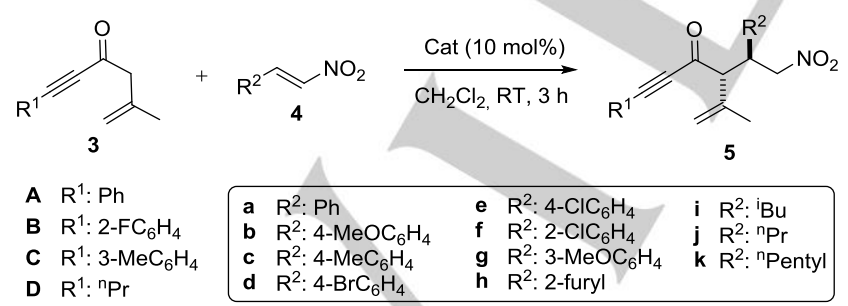

Scheme 2. Cataly tic addition of alkenyl ynones 3 to nitroolef ins and catalysts employ ed in this study.

As data in Table 2 show, the catalytic addition of $\mathbf{3 A}$ to aromatic nitroolefins $\mathbf{4 b}$ and $\mathbf{4 e}$ worked equally $w$ ell and adducts $5 \mathbf{A b}$ and $5 \mathrm{Ae}$ w ere obtained in good yield and high selectivity. The reaction $w$ as also very selective $w$ ith the $\beta$-alkyl substituted nitroolefin $4 \mathbf{i}$, although, as expected, progressed more slow ly (44\% conversion

Table 1. Cataly st screening for the reaction of $3 \mathrm{~A}$ with $4 \mathrm{a}$ to give $5 \mathrm{Aa}^{\left[{ }^{[a]}\right.}$ and cataly sts described in these manuscript.

\begin{tabular}{|c|c|c|c|c|c|}
\hline Entry & Cat & Produc & Yield [\%] $]^{[b]}$ & d. . $^{[c]}$ & $e e[\%]^{[d]}$ \\
\hline 1 & $\mathrm{C} 2$ & & 80 & $1.5: 1$ & 98 \\
\hline 2 & C3 & & 80 & $10: 1$ & 80 \\
\hline 3 & $\mathrm{C} 4$ & & 77 & $4: 1$ & 92 \\
\hline 4 & C5 & & $70^{[\mathrm{e}]}$ & $1: 1$ & 40 \\
\hline 5 & $\mathrm{C} 6$ & $5 \mathrm{Aa}$ & 82 & 19:1 & 94 \\
\hline 6 & C7 & & $90^{[f]}$ & $5.7: 1$ & 59 \\
\hline
\end{tabular}

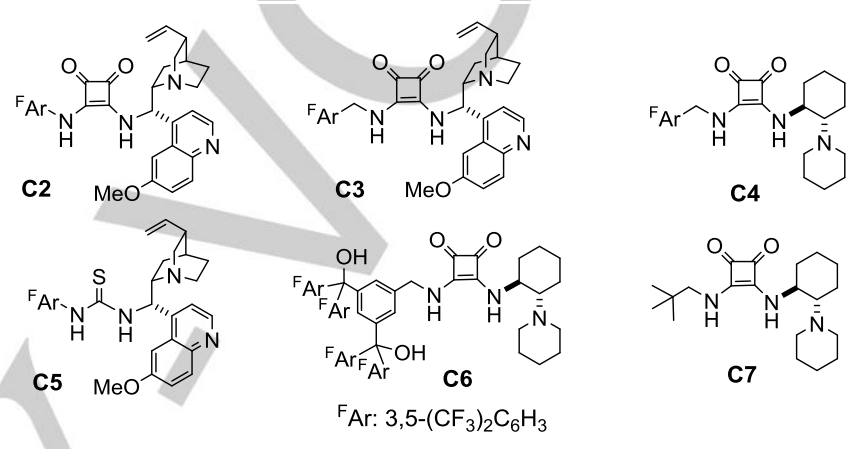

[a] Reactions run at $0.2 \mathrm{mmol}$ scale in $0.2 \mathrm{~mL} \mathrm{CH}_{2} \mathrm{Cl}_{2}$; mol ratio of $3 \mathrm{~A} / 4 \mathrm{a} / \mathrm{cat}$ 2:1:0.1. [b] Combined yield of diastereomers after chromatography. [c] Determined by chiral HPLC afterfiltration through a short path of $\mathrm{SiO}_{2}$. [d] $\mathrm{Ee}$ of major diastereomer determined by chiral HPLC. [e] Reaction conversion. [f] Conversion af ter $3 \mathrm{~h}$ reaction; $73 \%$ isolated y ield.

Table 2. C6-cataly zed conjugate addition of alkeny l y nones $\mathbf{3}$ to nitroolefins 4. ${ }^{[a]}$<smiles>C=C(C)C(C[N+](=O)[O-])C(C(=O)C#Cc1ccccc1)c1ccccc1</smiles>

$82 \%$, dr $19: 1,94 \%$ ee<smiles>C=C(C)C(C[N+](=O)[O-])C(CC(C)C)C(=O)C#Cc1ccccc1</smiles>

$5 \mathbf{A} \mathbf{i}$

$30 \%(44 \%$ conv. $)$ $d r>20: 1,92 \%$ ee

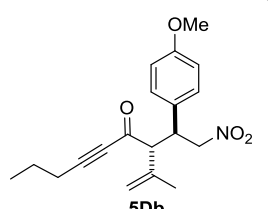

$5 \mathrm{Db}$

$70 \%$, dr $2.1: 1,93 \%$ ee<smiles>C=C(C)[C@H](C(=O)C#Cc1ccccc1)C(C[N+](=O)[O-])c1ccc(OC)cc1</smiles>

$75 \%$, dr $6.7: 1,98 \%$ ee<smiles>C=C(C)C(C(=O)C#Cc1ccccc1F)[C@@H](C[N+](=O)[O-])c1ccccc1</smiles>

$85 \%$, dr $15.7: 1,99 \%$ ee<smiles>C=C(C)[C@H](C(=O)C#Cc1ccccc1)C(C[N+](=O)[O-])c1ccc(Cl)cc1</smiles>

$80 \%$, dr $15.7: 1,93 \%$ ee<smiles>C=C(C)[C@H](C[N+](=O)[O-])C(C(=O)C#Cc1cccc(C)c1)c1ccccc1</smiles>

$75 \%$, dr $9: 1,95 \%$ ee [a] Reactions run at $0.2 \mathrm{mmol}$ scale in $0.2 \mathrm{~mL} \mathrm{CH}_{2} \mathrm{Cl}_{2} ; \mathrm{mol}$ ratio of $3 / 4 /$ catalyst $2: 1: 0.1$. Variable amounts of isomerized starting material were observ ed in most entries; yield of major diastereomer after chromatography, except for 5Db (combined y ield). Dr and ee determined by chiral HPLC analy sis. 
after $3 \mathrm{~h}$ ). Ynone substrates $w$ ith other aromatic substituents at the alkynyl moiety (adducts $5 \mathrm{Ba}, \mathbf{5 C a}$ ) or even alkyl substituents (5Db) were well tolerated too. These results constitute the first evidence of Brønsted base catalyzed Michael additions of $\alpha, \beta$ ynones that generate two adjacent tertiary stereocenters in highly enantio- and diastereoselective manner. One feature of these reactions is that whilst isomerization of the double bond on the new ly formed adducts w as not observed, the starting allyl ynones 3 isomerized to the respective vinyl ynones to some extent. However, the impact of this process on the reaction yield was negligible upon the use of two equivalents of the starting ynone. Some control experiments to assess the stability of products tow ards epimerization or double bond isomerization under the reaction conditions employed were carried out. For instance, w hen a solution of each adduct $\mathbf{5}$ w as stirred at room temperature overnight in the presence of $10 \mathrm{~mol} \% \mathbf{C 4}$, no change in the configurational integrity of adducts, nor appreciable isomerization, w ere observed.

We next studied the reaction outcome involving allyl ynones with a 1,2-disubstitution pattern on the olefin, which turned out to be strongly catalyst-dependent. Thus, as Table 3 show s, the reaction of $6 \mathrm{~A}$ with nitrostyrene $\mathbf{4 a}$ in the presence of catalyst $\mathbf{C} 4$ at room temperature overnight led to a mixture of adduct $\mathbf{7 A a}$ and its isomer $\mathbf{8 A a}$ in a 66:34 ratio (entry 1 ). In contrast, the same reaction promoted by catalyst $\mathbf{C 6}$ cleanly led to $\mathbf{7 A a}$ as the only isolated product, which was obtained as a mixture of diastereomers each in very high enantioselectivity (entry 2). A similar trend $w$ as observed in the reactions of ynone $6 \mathrm{~A}$ with nitroolefins $\mathbf{4 c}$ and $\mathbf{4 f}$, and of ynone $6 \mathrm{E}$ with $\mathbf{4 a}$. Thus, exclusive formation of the $\alpha$-addition products 7Ac, 7Af and 7Ea was observed using catalyst C6 (entries 4, 6 and 7), whereas with catalyst $\mathbf{C} 4$ mixtures of products $\mathbf{7}$ and $\mathbf{8}$ were obtained in ratios of $83: 17$ and $81: 19$, respectively (entries 3 and 5). As before, control experiments $w$ ith adducts 7 (unaltered material recovered

Table 3. Reaction of $\alpha$-alkeny I ketones 6: no isomerization with catalyst C6. ${ }^{\text {[a] }}$

\begin{tabular}{lllllllll}
\hline & & & & & \\
\end{tabular}

[a] Reactions run at $0.2 \mathrm{mmol}$ scale in $0.6 \mathrm{~mL} \mathrm{CH}_{2} \mathrm{Cl}_{2}$; mol ratio of $6 / 4 / \mathrm{cat}$ 2:1:0.1. [b] Determined by ${ }^{1} \mathrm{H}$ NMR. [c] Yield of pure 7 af ter chromatography. [d] Determined by chiral HPLC. after stirring a solution of the adduct in the presence of $10 \mathrm{~mol} \%$ C6 at room temperature overnight) demonstrated their stability tow ards double bond isomerization or epimerization. Tw o general conclusions can be brought from these and the previous ${ }^{[11]}$ results involving vinylogous alkynyl ketone enolates: (i) Brønsted base catalyzed additions of allyl alkynyl ketones proceed in all cases tested with high $\mathrm{C} \alpha$ selectively, and (ii) the tendency of the allylic ynone products tow ards double bond isomerization depends primarily on the alkene substitution pattern, but also the catalyst employed. Isomerization can be totally cancelled by choosing the right Brønsted base catalyst, e.g. C6, providing adducts with two contiguous stereocenters in very high enantioselectivity and diastereomeric ratios from moderate to excellent.

Benzylic alkynyl ketones as nucleophiles. Although the above results were encouraging, the question of whether this method is suitable for a broader range of ynone compounds remained unanswered so far. Particularly, simple alkyl ynones, such as methyl ynones, had been previously show $n$ unable to react $w$ ith nitrostyrene in the presence of typical Brønsted base catalysts. ${ }^{[10]}$ However, recent work by our ow $n$ group revealed some particularly active benzylic ketones to be amenable substrates for Brønsted base-assisted activation. ${ }^{[15]}$ Accordingly, benzylic ynones were envisioned as candidates for the evaluation of the method generality. A range of benzylic ynones 9-14 were easily accessible for the reaction screening which was initiated $w$ ith ynone $\mathbf{9 A}$ and $\beta$-arylsubstituted nitroolefins $\mathbf{4 b}$ in the presence of<smiles>[R]C#CCCBr</smiles>

9 Ar: $\mathrm{Ph}$

10 Ar: 4- $-\mathrm{MeC}_{6} \mathrm{H}_{4}$ 11 Ar: $3-\mathrm{MeC}_{6} \mathrm{H}_{4}$

12 Ar: $4-\mathrm{MeOC}_{6} \mathrm{H}_{4}$

13 Ar: $4-\mathrm{ClC}_{6} \mathrm{H}_{4}$

$14 \mathrm{Ar}: 3-\mathrm{ClC}_{6} \mathrm{H}_{4}$<smiles>[R]C(C[N+](=O)[O-])C([Al])C(=O)C#[R]</smiles>

$15 \mathrm{Ar}: \mathrm{Ph}$

16 Ar: 4- $\mathrm{MeC}_{6} \mathrm{H}_{4}$ 17 Ar: $3-\mathrm{MeC}_{6} \mathrm{H}_{4}$ 18 Ar: $4-\mathrm{MeOC}_{6} \mathrm{H}_{4}$ 19 Ar: $4-\mathrm{ClC}_{6} \mathrm{H}_{4}$ 20 Ar: $3-\mathrm{ClC}_{6} \mathrm{H}_{4}$
Scheme 3. Cataly tic reaction of benzy lic y nones 9-14 and nitroolef ins 4 .

Table 4. Cataly st screening for the reaction of y none $9 \mathrm{~A}$ and nitroolef in $4 \mathrm{~b}$ to $y$ ield adduct $15 \mathbf{A b}$. ${ }^{[a]}$

\begin{tabular}{llllll}
\hline Entry & Cat & $\mathrm{t}[\mathrm{h}]$ & ${\text { Yield }[\%]^{[\mathrm{b}]}}$ & d.r. $^{[\mathrm{c}]}$ & ee [\% $]^{[\mathrm{c}]}$ \\
\hline 1 & $\mathbf{C 2}$ & 2.5 & 95 & $1: 1$ & ND \\
2 & C3 & 2.5 & 96 & $2.8: 1$ & $82(92)$ \\
3 & C4 & 4.5 & 99 & $3.3: 1$ & $91(97)$ \\
4 & C6 & 6 & 97 & $5.7: 1$ & $96(99)$ \\
5 & C7 & 6 & 90 & $1.5: 1$ & -- \\
\hline
\end{tabular}

[a] Reactions run at $0.1 \mathrm{mmol}$ scale in $0.3 \mathrm{~mL} \mathrm{CH}_{2} \mathrm{Cl}_{2}$; mol ratio of $9 \mathrm{~A} / 4 \mathrm{~b} / \mathrm{cat}$ 1:1.2:0.1. [b] Combined y ield of diastereomers af ter chromatography. [c] Determined by chiral HPLC bef ore chromatography . 
Table 5. Scope of the catalytic, enantioselective addition of alkynyl ketones 9-14 to nitroolef ins $4 .^{[a]}$<smiles>O=C(C#Cc1ccccc1)C(C[N+](=O)[O-])C(=O)c1ccccc1</smiles>

C4 $3 \mathrm{~h} 80 \%$, dr $5.7: 1,93 \%$ ee $(98 \%$ ee $)$ C6 $4 \mathrm{~h} 86 \%$, dr $4.9: 1,96 \%$ ee $(99 \%$ ee)<smiles>CC(C)CC(C[N+](=O)[O-])C(C(=O)C#Cc1ccccc1)c1ccccc1</smiles>
15Ai

C6 $144 \mathrm{~h}, 71 \%{ }^{[\mathrm{b}]}$, dr $2.6: 1,94 \%$ ee $(98 \%$ ee $)$

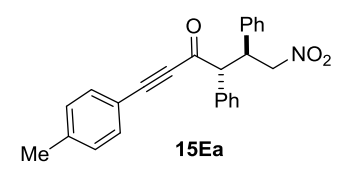

C6 $16 \mathrm{~h}, 87 \%$, dr 4:1, 96\% ee (ee nd)<smiles>O=C(C#Cc1ccc(Cl)cc1)[C@H](c1ccc(Cl)cc1)C(C[N+](=O)[O-])c1ccccc1</smiles>

C4 $16 \mathrm{~h}, 77 \%$, dr $3.3: 1,90 \%$ ee $(98 \%$ ee $)$ C6 $16 \mathrm{~h}, 90 \%$, dr $4.6: 1,92 \%$ ee $(99 \%$ ee $)$<smiles>Cc1ccc(C(C(=O)C#Cc2ccccc2)C(C[N+](=O)[O-])c2ccccc2)cc1</smiles>

C4 $3 \mathrm{~h}, 85 \%$, dr $3.2: 1,90 \%$ ee $(99 \%$ ee) C6 $16 \mathrm{~h}, 90 \%$, dr $4.9: 1,84 \%$ ee $(99 \%$ ee $)$<smiles>Cc1ccc([C@H](C(=O)C#Cc2ccccc2)C(C[N+](=O)[O-])c2ccc(Br)cc2)cc1</smiles>
C6 $16 \mathrm{~h}, 93 \%$, dr $6.7: 1,96 \%$ ee $(99 \%$ ee $)$

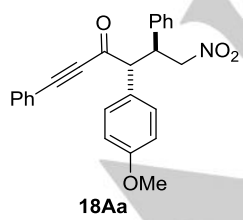

C6 $16 \mathrm{~h}, 96 \%$, dr 4:1, 96\% ee (99\% ee)
C4 $4 \mathrm{~h}, 89 \%$, dr $2.6: 1,94 \%$ ee $(98 \%$ ee)

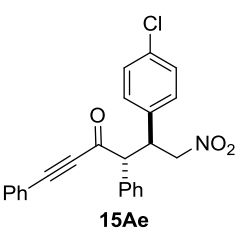

C4 $3 \mathrm{~h} 99 \%$, dr 3.3:1, $94 \%$ ee $(98 \%$ ee $)$ C6 $6 \mathrm{~h}$ 93\%, dr 5.2:1, 99\% ee $(99 \%$ ee $)$<smiles>CC(C)(C)CC(C[N+](=O)[O-])[C@@H](C(=O)C#Cc1ccccc1)c1ccccc1</smiles>

C6 $144 \mathrm{~h}, 68 \%{ }^{[\mathrm{c}]}$, dr $2.8: 1,94 \%$ ee $(88 \%$ ee $)$<smiles>O=C(C#Cc1ccc(Cl)cc1)[C@H](c1ccccc1)C(C[N+](=O)[O-])c1ccccc1</smiles>

C4 $16 \mathrm{~h}, 77 \%$, dr 2.7:1, 90\% ee ( $98 \%$ ee) C6 $16 \mathrm{~h}, 87 \%$, dr $3: 1,96 \%$ ee $(99 \%$ ee)

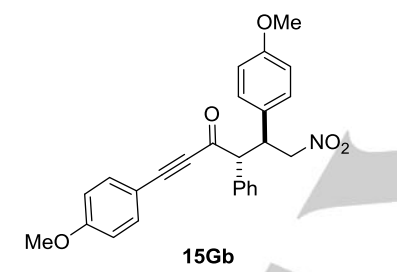

C6 $16 \mathrm{~h}, 86 \%$, dr $6.7: 1,94 \%$ ee $(99 \%$ ee $)$

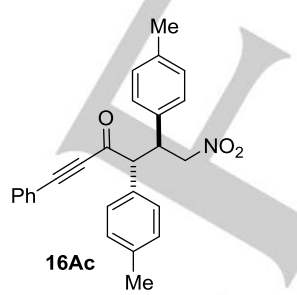

C6 $16 \mathrm{~h}, 90 \%$, dr $4.9: 1,96 \%$ ee $(98 \%$ ee $)$

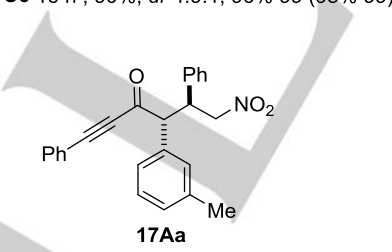

C6 $16 \mathrm{~h}, 96 \%$, dr $6.1: 1,94 \%$ ee $(99 \%$ ee)

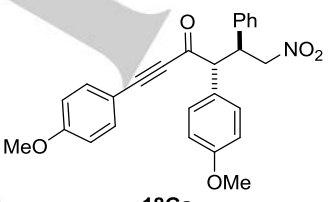

$18 \mathrm{Ga}$
C6 $16 \mathrm{~h}, 96 \%$, dr $8.1: 1,98 \%$ ee $(99 \%$ ee)

(Continue...)

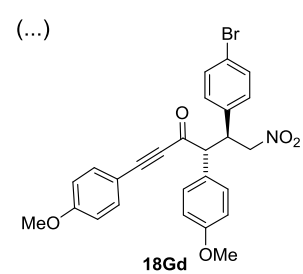

C6 $16 \mathrm{~h}, 82 \%$, dr $6.7: 1,96 \%$ ee (99\% ee)

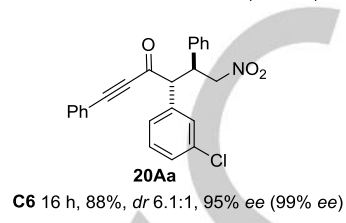

[a] Reactions run at $0.1 \mathrm{mmol}$ scale in $0.3 \mathrm{~mL} \mathrm{CH}_{2} \mathrm{Cl}_{2}$; mol ratio of $\mathbf{9 - 1 4 / 4 / c a t ~}$ $1: 1.2: 0.1$. Combined y ield of diastereomers af ter chromatography; $d r$ and ee determined by chiral HPLC. In parentheses the ee of minor isomer. [b] Conversion of $84 \%$. [c] Conversion of $74 \%$.

several bifunctional squaramide catalysts. ${ }^{[13]}$ As data in Scheme 3 and Table 4 show, the reaction in the presence of $\mathbf{C 2}$ took place in a few hours to give product $15 \mathrm{Ab}$ in good yield, albeit no diastereocontrol at all (entry 1). Diastereoselectivity $w$ as improved using catalyst C3 (entry 2) and even more with C4 (entry 3 ) that afforded product $15 \mathbf{A b}$ in $3.3: 1 \mathrm{dr}$ and $91 \%$ and $97 \%$ ee, respectively, for each isomer. Further screening show ed catalyst C6 the most selective once more $(5.7: 1 d r, 96 \%$ and $99 \%$ ee, entry 4), whilst its bis-O-trimethylsilyl analog (see the supporting information) led to slightly low er diastereoselectivity (3.2:1 dr, $98 \%$ and $99 \%$ ee). For comparative purposes, the reaction with catalyst $\mathbf{C 7}$, bearing a bulky neopentyl group at the squaramide terminus, was carried out, but again led to an almost equimolar mixture of diastereomers. These results support the initial assumption that steric effects alone may not suffice to explain the salient performance of $\mathbf{C 6}$. This trend in catalyst behavior was confirmed along the exploration of the reaction scope $w$ ith regard to the nitroolefin. As show $n$ in Table 5, when the reaction of $9 A$ with $4 \mathrm{a}$ and $4 \mathrm{e}$ was promoted by catalysts $\mathbf{C 4}$ and $\mathbf{C 6}$ similar results were produced albeit the latter provided somew hat better diastereoselectivity. $\beta$-Alkyl substituted nitroolefins as well as a variety of electron-poor, and rich, $\beta$-aryl substituted nitroolefins participate well in the reaction of alkynylketones 9-14 to afford adducts 15-20 in very high yield, good diastereoselectivity and nearly perfect enantioselectivity for most cases, independently of the substitution pattern of each reaction component. The absolute configuration of adduct $15 \mathrm{Ab}$ w as established by single crystal $\mathrm{X}$ ray structure analysis ${ }^{[17]}$ and for the remaining adducts was assumed by analogy on the bases of a uniform reaction mechanism.

Benzyloxymethyl alkynyl ketones as nucleophiles. In view of the successful reactivity of both benzyl and allyl ynones, the behavior of ynones $w$ ith an alkoxymethyl sidechain w as explored next. The heteroatom-substituted sidechain w ould not only render synthetically appealing adducts, but also increased acidity to substrates for Brønsted base catalyst activation. Concordant with our expectations, it $w$ as found that ynones 21, bearing a 
benzyloxymethyl side-arm, are indeed competent for the catalyzed reaction with nitroolefins. Among the catalysts examined for these reactions, ${ }^{[13]} \mathbf{C 3}$ resulted superior. For example, as data in Table 6 show, the reactions of $21 \mathrm{~A}$ with nitrostyrenes $\mathbf{4 a - g}$ in the presence of $10 \mathrm{~mol} \%$ C3 afforded adducts 22Aa-g in excellent diastereomeric ratio (typically greater than 10:1) and ee's up to $99 \%$ for the major diastereomer. The reaction $w$ ith the $\beta$-heteroaromatic nitroolefin $\mathbf{4 h}$, or the most challenging alkyl nitroolefin $\mathbf{4 j}$, also provided the corresponding adducts $22 \mathbf{A h}, 22 \mathbf{A j}$ in very good yields, diastereomeric ratios of $10: 1$ and 6.7:1, and enantioselectivities of $99 \%$ and $96 \%$, respectively. Similarly, the alkyl substituted ynone 21D reacted smoothly with either aromatic or aliphatic nitroolefins giving access to adducts 22Da, 22Dj in nearly perfect stereoselectivity. Absolute configuration of adduct 22Ae w as established by single crystal X-Ray structure analysis ${ }^{[17]}$ and for the remaining adducts $22 \mathrm{w}$ as assumed by analogy on the bases of a uniform reaction mechanism.

Table 6. Cataly tic, enantioselective reaction of benzy loxy y nones $\mathbf{2 1}$ with nitroolef ins $4 .^{[a]}$

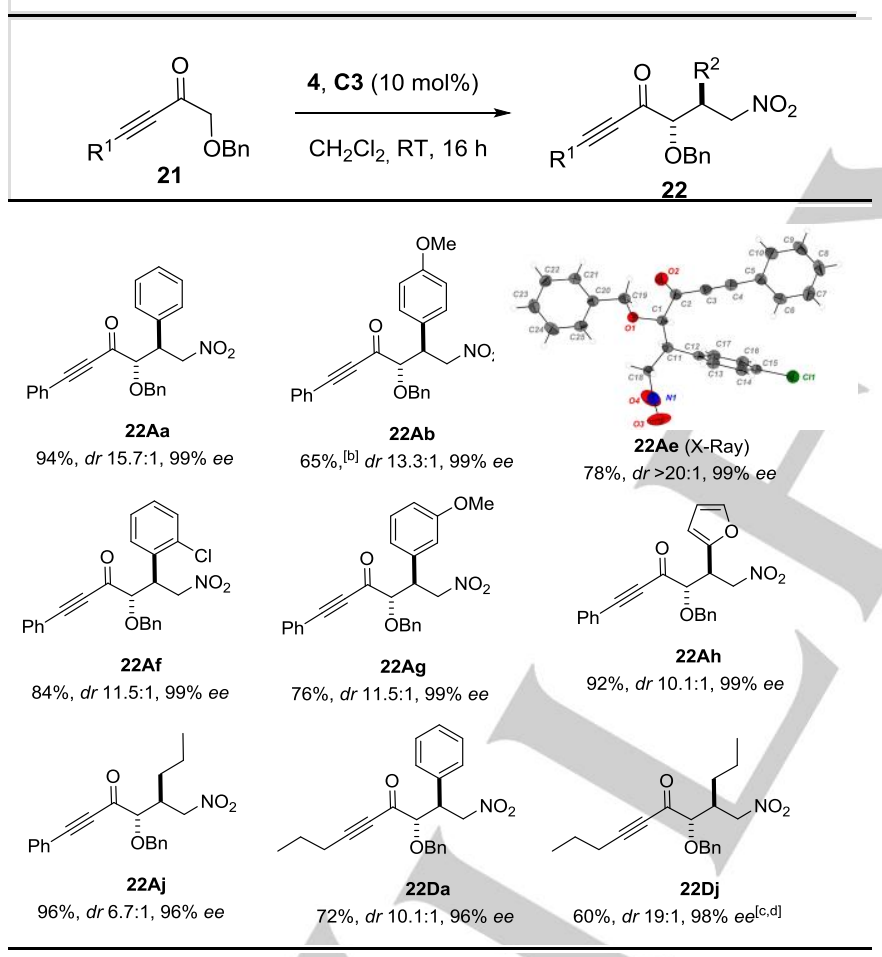

[a] Reactions run at $0.2 \mathrm{mmol}$ scale in $0.2 \mathrm{~mL} \mathrm{CH}_{2} \mathrm{Cl}_{2}$; mol ratio of $21 / 4$ /catalyst $1: 2: 0.1$. Yields of isolated product after chromatography; ee determined by chiral HPLC before chromatography. [b] $80 \%$ conversion after 72 h. [c] Reaction run at $0.2 \mathrm{mmol}$ scale in $0.2 \mathrm{~mL} 1,2$-DCE using 3 equiv. of nitroolefin. [d] $65 \%$ conv ersion af ter $48 \mathrm{~h}$.

Eaboration of adducts. An interesting aspect of the above catalytic reactions is that adducts can be transformed into polyfunctionalized structures with tw $o$ or more contiguous tertiary stereocenters using simple chemical protocols. For instance, reduction of the alkynyl moiety in adducts provides dissymmetric alkyl alkyl ketone products with tw o tertiary stereocenters at $\alpha$ and $\beta$ positions. For instance, catalytic hydrogenation of $15 \mathrm{Ab}$ afforded 23 in $97 \%$ yield (Scheme 4), the $\alpha$-branched ketone product formally derived from the yet unrealized site- and stereoselective $\alpha$-alkyltion of the corresponding phenethyl ketone.

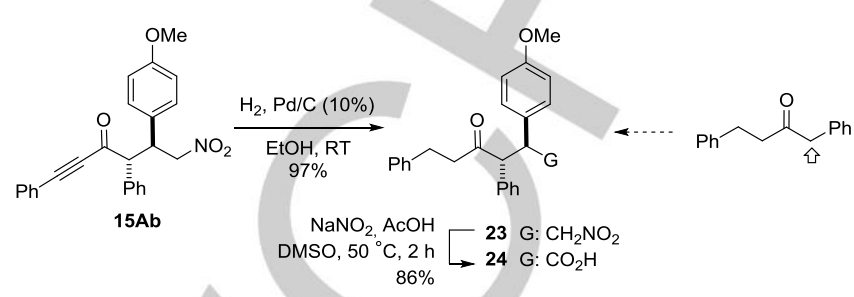

Scheme 4. Reduction of adducts to $\alpha$-branched alky l alky I ketones.

Alternatively, substrate-controlled stereoselective reduction of the ketone carbonyl to carbinol $w$ as feasible according to two stereodivergent pathways (Scheme 5). On the one hand, reduction of 22Ab with K-Selectride proceeded via a Felkin-Anh model ${ }^{[18]}$ to afford syn alcohol 25 exclusively, while chelation controlled reduction w ith $\mathrm{NaBH}_{4}$ afforded the complementary anti alcohol $^{[19]} 27$, in both cases with good isolated yields. The nitro group in these molecules is amenable for efficient transformation into a carboxylic acid function upon oxidation according to Mioskow ski ${ }^{[20]}$ conditions, as illustrated by the conversion of $\mathbf{2 3}$ to acid $24(86 \%)$ (Scheme 4), 25 to $26(77 \%)$ and 27 to $28(84 \%)$, respectively, Scheme 5 .

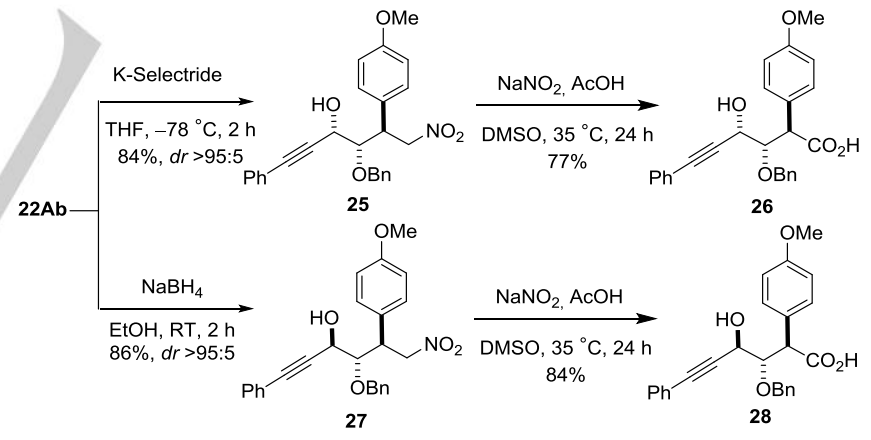

Scheme 5. Diastereodiv ergent reduction of the ketone carbony I to syn and antidiol units.

Further synthetic interest of the present catalytic addition reactions is derivable from intramolecular carbofunctionalizations of the alkynyl moiety in adducts. As show $\mathrm{n}$ in Scheme 6, Larock's ipso-halocyclisation ${ }^{[21]}$ of adduct 18Aa furnished spirocycle 29 in $86 \%$ yield, while heating adduct $18 \mathrm{Ga}$ at $65^{\circ} \mathrm{C}$ in the presence of $\mathrm{Cu}(\mathrm{II})$, according to the method of Taylor and Unsw orth, ${ }^{[22]}$ led to the spirocycle 31 . These spirocyclic quinones are easily converted into compounds $\mathbf{3 0}$ and $\mathbf{3 2}$, respectively, which display a tricyclic carbon core similar to that present in homodimer icin $A,{ }^{[23]}$ a structurally intricate compound whose enantioselective chemical synthesis is still pending. ${ }^{[24]}$ 

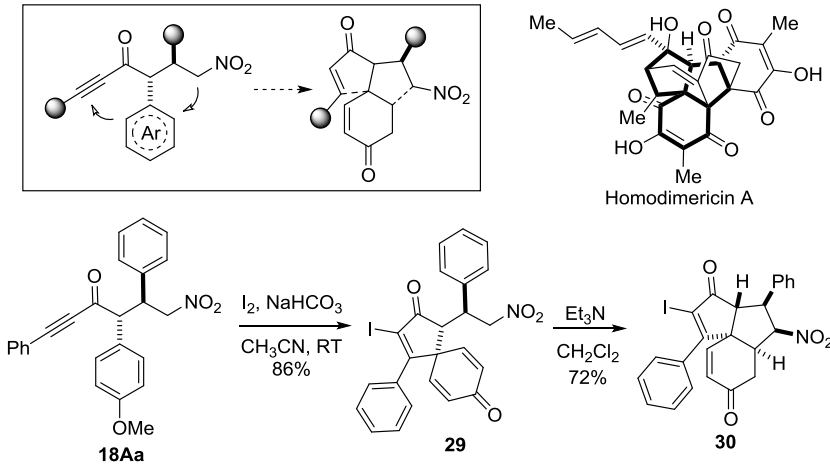

Homod

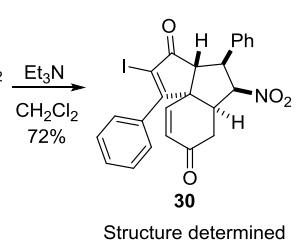
by NMR (ref 13)

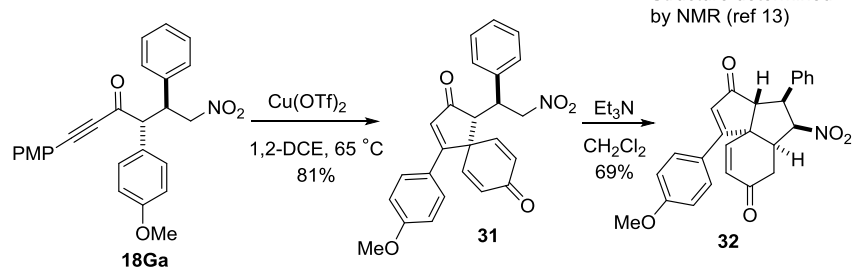

Scheme 6. Elaboration of adducts into carbocy cles of intricate structure.

\section{Conclusions}

In conclusion, conjugate additions of enolizable $\alpha, \beta$-ynones to nitroolefins is feasible in a highly selective fashion in the presence of tertiary amine/squaramide bifunctional catalysts, affording an atom economic route to densely functionalized building-blocks . For the new $\mathrm{C}-\mathrm{C}$ bond forming reaction not only allyl ynones, but also benzylic ynones and alkoxymethyl ynones are suitable ketone donors, thus complementing the few existing direct approaches for the $\alpha$-functionalization of alkynyl ketones. Elaboration of the $\alpha$-branched ynone adducts through simple protocols allows an access to stereochemically complex structures, both acyclic and intricate tricyclic carbon skeletons, in optically pure form.

\section{Experimental Section}

General Procedure for the Michael reaction: To a solution of the corresponding ynone $(0.1 \mathrm{mmol}, 1$ eq. $)$ and nitroalkene $(0.12 \mathrm{mmol}, 1.2$ eq.) in dichloromethane $(0.3 \mathrm{~mL})$ at room temperature the catalyst $(0.01$ $\mathrm{mmol}, 10 \mathrm{~mol} \%$ ) was added and the resulting mixture was stirred at the same temperature for the time indicated in the tables. Then the mixture was directly submitted to a flash column chromatography (eluent hexane/ethyl acetate).

Compound 15Ab: The title compound was prepared from 1,4diphenylbut-3-yn-2-one (9A) $(22.0 \mathrm{mg}, 0.1 \mathrm{mmol})$ according to the general procedure with cat $\mathbf{C 6}$, affording a 5.7:1 mixture of diastereomers. Yield: $38.6 \mathrm{mg}, 97 \%$. Crystallized from $\mathrm{Et}_{2} \mathrm{O}$. White solid. $[\alpha]_{\mathrm{D}}{ }^{25}=-62.9^{\circ}(c=0.53$, $96 \%$ ee, $\mathrm{CH}_{2} \mathrm{Cl}_{2}$ ). m.p. $156-158 \stackrel{\circ}{\circ} \mathrm{C} .{ }^{1} \mathrm{HNMR}\left(300 \mathrm{MHz}, \mathrm{CDCl}_{3}\right), \delta: 7.59$ $7.29(\mathrm{~m}, 12 \mathrm{H}), 6.89(\mathrm{~d}, \mathrm{~J}=8.7 \mathrm{~Hz}, 2 \mathrm{H}), 4.56-4.28(\mathrm{~m}, 4 \mathrm{H}), 3.79(\mathrm{~s}, 3 \mathrm{H}) .{ }^{13} \mathrm{C}$ $\operatorname{NMR}\left(75 \mathrm{MHz}_{2} \mathrm{CDCl}_{3}\right) \delta: 184.6,160.0,134.8,133.7,131.6,130.3,129.9$, 129.6, 129.5, 129.3, 120.2, 115.1, 110.7, 94.0, 88.1, 79.6, 64.5, 55.9, 45.5. UPLC-DAD-QTOF: $\mathrm{C}_{25} \mathrm{H}_{22} \mathrm{NO}_{4}[\mathrm{M}+\mathrm{H}]^{+}$calcd.: 400.1549 , found: 400.1550 .

Compound 18Aa: Prepared from 1-(4-methoxyphenyl)-4-phenylbut-3-yn2-one (12A) (25.0 mg, $0.1 \mathrm{mmol}$ ) according to the general procedure with cat C6, affording a 4.1:1 mixture of diastereomers. Yield: $38.34 \mathrm{mg}, 96 \%$. Crystallized from $\mathrm{Et}_{2} \mathrm{O}$. White solid. $[\alpha]_{D}{ }^{25}=-55.5^{\circ}(c=0.3,96 \%$ ee, $\mathrm{CH}_{2} \mathrm{Cl}_{2}$ ). m.p. $134-136{ }^{\circ} \mathrm{C} .{ }^{1} \mathrm{H}$ NMR $\left(300 \mathrm{MHz} \mathrm{CDCl}_{3}\right), \delta: 7.52-7.26(\mathrm{~m}$, $14 \mathrm{H}), 6.99(\mathrm{~d}, J=8.7 \mathrm{~Hz}, 2 \mathrm{H}), 4.53-4.32(\mathrm{~m}, 4 \mathrm{H}), 3.85(\mathrm{~s}, 3 \mathrm{H}) .{ }^{13} \mathrm{C} N M R$ $\left(75 \mathrm{MHz} \mathrm{CDCl}_{3}\right) \delta: 182.7,158.8,136.1,131.8,129.7,128.9,127.8,127.4$, 127.0, 126.9, 124.6, 118.4, 113.9, 92.0, 86.3, 78.0, 61.5, 54.1, 44.3. UPLC-DAD-QTOF: $\mathrm{C}_{25} \mathrm{H}_{22} \mathrm{NO}_{4}[\mathrm{M}+\mathrm{H}]^{+}$calcd.: 400.1549, found:400.1551.

Compound 18Ga: Prepared from 1,4-bis(4-methoxyphenyl)but-3-yn-2one $(12 \mathrm{G})(28.0 \mathrm{mg}, 0.1 \mathrm{mmol})$ according to the general procedure with cat C6, affording a 8.1:1 mixture of diastereomers. Yield: $41.2 \mathrm{mg}, 96 \%$. Crystallized from $\mathrm{Et}_{2} \mathrm{O}$. White solid. $[\alpha]_{D}^{25}=-1.4^{\circ}\left(c=0.2,98 \%\right.$ ee, $\mathrm{CH}_{2} \mathrm{Cl}_{2}$ ). m.p. 142-144 으. ${ }^{1} \mathrm{HNMR}\left(300 \mathrm{MHz}, \mathrm{CDCl}_{3}\right), \delta: 7.44(\mathrm{~d}, \mathrm{~J}=9.0 \mathrm{~Hz}, 2 \mathrm{H})$, $7.40(\mathrm{~d}, J=8.7 \mathrm{~Hz}, 2 \mathrm{H}), 7.38-7.29(\mathrm{~m}, 5 \mathrm{H}), 6.98(\mathrm{~d}, J=8.8 \mathrm{~Hz}, 2 \mathrm{H}), 6.88$ (d, J=8.9 Hz, 2H), 4.51-4.30(m, 4H), $3.85(\mathrm{~s}, 3 \mathrm{H}), 3.85(\mathrm{~s}, 3 \mathrm{H}) .{ }^{13} \mathrm{C} N M R$ $\left(75 \mathrm{MHz} \mathrm{CDCl}_{3}\right) \delta: 184.6,160.6,138.1,135.8,131.7,130.7,129.6,128.8$, $128.7,128.2,126.7,115.7,115.0,110.7,95.0,88.3,79.6,63.3,56.0,46.3$ UPLC-DAD-QTOF: $\mathrm{C}_{26} \mathrm{H}_{24} \mathrm{NO}_{5}[\mathrm{M}+\mathrm{H}]^{+}$calcd.: 430.1654 , found: 430.1658 . UPLC-DAD-QTOF: $\quad \mathrm{C}_{26} \mathrm{H}_{23} \mathrm{NO}_{5} \mathrm{Na} \quad[\mathrm{M}+\mathrm{Na}]^{+} \quad$ calcd.: 452.1474 , found:452.1470.

Compound 22Ab: Prepared starting from ynone 21A (50 mg, $0.2 \mathrm{mmol}$ ) according to the general procedure with cat $\mathbf{C} 3$. Orange oil, yield: $56 \mathrm{mg}$ $(65 \%) .[\mathrm{a}]_{\mathrm{D}}{ }^{25}=+26.1^{\circ}\left(\mathrm{c}=1,>99 \%\right.$ ee, $\left.\mathrm{CH}_{2} \mathrm{Cl}_{2}\right) .{ }^{1} \mathrm{HNMR}\left(300 \mathrm{MHz}, \mathrm{CDCl}_{3}\right)$ ठ 7.63-7.28 (m, 11H), 7.25-7.18 (m, 2H), 6.90-6.82 (m, 2H), 4.95-4.68 $(\mathrm{m}, 4 \mathrm{H}), 4.46(\mathrm{~d}, J=11.3 \mathrm{~Hz}, 1 \mathrm{H}), 4.15(\mathrm{ddd}, J=9.3,7.0,4.9 \mathrm{~Hz}, 1 \mathrm{H}), 3.78$ $(\mathrm{s}, 3 \mathrm{H}) .{ }^{13} \mathrm{C}$ NMR $\left(75 \mathrm{MHz}, \mathrm{CDCl}_{3}\right) \delta 187.5,160.6,137.5,134.5,132.4$, 131.4, 130.5, 129.8, 129.7, 129.4, 129.3, 128.2, 120.4, 115.5, 87.4, 87.2, 77.7, 74.2, 56.3, 46.6. UPLC-DAD-QTOF: $\mathrm{C}_{26} \mathrm{H}_{24} \mathrm{NO}_{5}[\mathrm{M}+\mathrm{H}]^{+}$calcd.: 430.1654 , found: 430.1654 .

Syn selective reduction of 22Ab: To a solution of $22 \mathrm{Ab}(0.2 \mathrm{mmol}, 86$ $\mathrm{mg})$ in dry THF $(0.5 \mathrm{~mL})$ at $-78^{\circ} \mathrm{C}$ a solution of K-selectride in THF (1M, 3 equiv., $0.6 \mathrm{mmol}, 0.6 \mathrm{~mL}$ ) was added and the mixture was stirred at that temperature for 2 hours. Then water $(0.2 \mathrm{~mL})$ and $\mathrm{EtOH}(0.4 \mathrm{~mL})$ were successively added, and after 5 min of stirring $\mathrm{H}_{2} \mathrm{O}_{2}(30 \%, 0.4 \mathrm{~mL})$ was added. The reaction mixture wasallowed to rise to room temperature and the mixture was stirred for an additional $10 \mathrm{~min}$. Then, it was diluted with EtOAc $(5 \mathrm{~mL})$ and water $(5 \mathrm{~mL})$. The aqueous phase was extracted with EtOAc $(3 \times 5 \mathrm{~mL})$, the organic layers were combined, and dried with $\mathrm{MgSO}_{4}$, filtered and the solvent was evaporated under reduced pressure. The resulting crude material waspurified by flash column chromatography (eluent hexane/ethyl acetate $80: 20$ ) to afford compound $\mathbf{2 5}$ as a yellow oil (dr: $>95: 5)$. Yield: $70 \mathrm{mg}(84 \%) .[\alpha]_{D^{25}}=+3.4^{\circ}\left(c=0.1, \mathrm{CH}_{2} \mathrm{Cl}_{2}\right.$, from adduct of $>99 \%$ ee $) .{ }^{1} \mathrm{H} \mathrm{NMR}\left(300 \mathrm{MHz}, \mathrm{CDCl}_{3}\right) \delta 7.46-7.26(\mathrm{~m}, 10 \mathrm{H}), 7.20-7.15$ $(\mathrm{m}, 2 \mathrm{H}), 6.92-6.87(\mathrm{~m}, 2 \mathrm{H}), 5.13(\mathrm{~d}, J=10.9 \mathrm{~Hz}, 1 \mathrm{H}), 4.91-4.84(\mathrm{~m}, 1 \mathrm{H})$, 4.84-4.79 (m, 1H), 4.62-4.49 (m, 1H), $4.39(\mathrm{~d}, J=1.4 \mathrm{~Hz}, 1 \mathrm{H}), 4.00-3.93$ (m, $2 \mathrm{H}), 3.81(\mathrm{~s}, 3 \mathrm{H}) .{ }^{13} \mathrm{C}$ NMR $\left(75 \mathrm{MHz} \mathrm{CDCl}_{3}\right) \delta 160.5,150.8,138.1$, 132.7, 131.2, 130.4, 129.9, 129.8, 129.6, 129.6, 129.5, 115.8, 89.6, 84.1, 78.8, 76.5, 63.1 , 56.4 , 46.4, 30.8. DAD-QTOF: $\mathrm{C}_{26} \mathrm{H}_{26} \mathrm{NO}_{5}[\mathrm{M}+\mathrm{H}]^{+}$calcd.: 432.1811, found: 432.1814 .

Anti selective reduction of $22 \mathrm{Ab}: \mathrm{NaBH}_{4}(16 \mathrm{mg}, 0.4 \mathrm{mmol}, 2$ equiv.) was added to a stirred mixture of compound $22 \mathrm{Ab}(0.2 \mathrm{mmol}, 86 \mathrm{mg})$ in $\mathrm{EtOH}(1 \mathrm{~mL})$ at room temperature. After $2 \mathrm{~h}$ the mixture was poured into saturated aqueous $\mathrm{NaHCO}_{3}$ and extracted with $\mathrm{Et}_{2} \mathrm{O}(3 \times 5 \mathrm{~mL})$. The combined organic extracts were washed with $\mathrm{H}_{2} \mathrm{O}(5 \mathrm{~mL})$ and brine $(5 \mathrm{~mL})$, and dried with $\mathrm{MgSO}_{4}$, filtered and the solvent was evaporated under reduced pressure. The resulting crude material was purified by flash column chromatography (eluent hexane/ethyl acetate 80:20) to afford compound 27 as a colourlessoil (dr: $>95: 5)$. Yield: $74 \mathrm{mg}(86 \%)$. [a] ${ }_{D}^{25}=$ $+18.3^{\circ}\left(c=0.3, \mathrm{CH}_{2} \mathrm{Cl}_{2}\right.$, from adduct of $>99 \%$ ee $) .{ }^{1} \mathrm{H} \mathrm{NMR}(400 \mathrm{MHz}$, 
$\left.\mathrm{CDCl}_{3}\right), \delta: 7.50-7.25(\mathrm{~m}, 10 \mathrm{H}), 7.24-7.20(\mathrm{~m}, 2 \mathrm{H}), 6.89-6.84(\mathrm{~m}, 2 \mathrm{H}), 5.02$ (dd, J=12.9, $5.0 \mathrm{~Hz}, 1 \mathrm{H}), 4.88(\mathrm{~d}, J=11.4 \mathrm{~Hz}, 1 \mathrm{H}), 4.73-4.62(\mathrm{~m}, 2 \mathrm{H}), 4.59$ (d, $J=3.5 \mathrm{~Hz}, 1 \mathrm{H}$ ), 4.03 (ddd, $J=9.8,7.5,5.1 \mathrm{~Hz}, 1 \mathrm{H}$ ), 3.93 (dd, $J=7.5,3.5$ $\mathrm{Hz}, 1 \mathrm{H}), 3.84-3.82(\mathrm{~m}, 1 \mathrm{H}), 3.80(\mathrm{~s}, 3 \mathrm{H}) .{ }^{13} \mathrm{CNMR}\left(101 \mathrm{MHz}, \mathrm{CDCl}_{3}\right), \delta$ : 159.2, 137.4, 131.8, 129.2, 129.0, 128.8, 128.7, 128.3, 128.2, 128.1, 122.0 114.4, 83.3, 74.7, 64.7, 55.2, 45.2, 29.7. DAD-QTOF: $\mathrm{C}_{26} \mathrm{H}_{26} \mathrm{NO}_{5}\left[\mathrm{M}+\mathrm{H}^{+}\right.$ calcd.: 432.1811, found: 432.1810 .

Procedure for the Nef oxidation of adducts 23, 25 and 27: (Mioskowski conditions) A solution of the corresponding diol (1 equiv.), sodium nitrite (3 equiv.) and acetic acid (10 equiv.) in DMSO ( $0.5 \mathrm{~mL} / 0.2 \mathrm{mmol}$ ) was stirred at 35 or $50^{\circ} \mathrm{C}$ for $24 \mathrm{~h}$. After this period, the reaction mixture was quenched with $\mathrm{HCl} 1 \mathrm{~N}(5 \mathrm{~mL})$ and the mixture was extracted with $\mathrm{Et}_{2} \mathrm{O}(4 \times 5 \mathrm{~mL})$. The combined organic phases were dried with $\mathrm{MgSO}_{4}$, filtered and the solvent was evaporated under reduced pressure. The resulting crude material waspurified by flash column chromatography.

Compound 24: Prepared from compound 23 (65 mg, $0.16 \mathrm{mmol})$ according to the general procedure. White solid, yield $53.8 \mathrm{mg}(86 \%)$. $[\alpha]_{D}^{25}=-129.6^{\circ}\left(c=0.1, \mathrm{CH}_{2} \mathrm{Cl}_{2}\right.$, from adduct of $96 \%$ ee). m.p. $144-146{ }^{\circ} \mathrm{C}$. ${ }^{1} \mathrm{H}$ NMR $\left(300 \mathrm{MHz}, \mathrm{CDCl}_{3}\right), \delta: 7.40-6.80(\mathrm{~m}, 14 \mathrm{H}), 4.53-4.33(\mathrm{~m}, 2 \mathrm{H})$, $3.82(\mathrm{~s}, 3 \mathrm{H}), 2.77-2.32(\mathrm{~m}, 4 \mathrm{H}) .{ }^{13} \mathrm{C} \mathrm{NMR}\left(75 \mathrm{MHz}, \mathrm{CDCl}_{3}\right)$, ठ: 207.6, 177.6 160.3, 141.6, 136.5, 133.4, 130.7, 130.0, 129.8, 129.4, 129.1, 129.0, 127,0 $115.3,62.3,56.3,54.1,45.4,30.1$. UPLC-DAD-QTOF: $\mathrm{C}_{25} \mathrm{H}_{24} \mathrm{O}_{4} \mathrm{Na}$ $[\mathrm{M}+\mathrm{Na}]^{+}$calcd.: 411.1572 , found: 411.1570

Compound 26: Prepared from compound 25 ( $86 \mathrm{mg}, 0.2 \mathrm{mmol}$ ) according to the general procedure. Colourless oil, yield $64 \mathrm{mg}(77 \%)$. $[\alpha]_{D}{ }^{25}=+13.5^{\circ}$ $\left(c=0.3, \mathrm{CH}_{2} \mathrm{Cl}_{2}\right.$, from adduct of $\left.99 \% \mathrm{ee}\right)$. IR $\left(\mathrm{v} / \mathrm{cm}^{-1}\right): 3356(\mathrm{O}-\mathrm{H}), 1716$ $(\mathrm{C}=\mathrm{O}) .{ }^{1} \mathrm{H}$ NMR $\left(300 \mathrm{MHz}, \mathrm{CDCl}_{3}\right), \delta: 8.00-7.91(\mathrm{~m}, 2 \mathrm{H}), 7.55-7.43(\mathrm{~m}$, $3 \mathrm{H}), 7.34-7.24(\mathrm{~m}, 3 \mathrm{H}), 7.23-7.14(\mathrm{~m}, 2 \mathrm{H}), 7.12-7.03(\mathrm{~m}, 2 \mathrm{H}), 6.95-6.86$ $(\mathrm{m}, 2 \mathrm{H}), 5.36(\mathrm{~d}, J=4.2 \mathrm{~Hz}, 1 \mathrm{H}), 4.77(\mathrm{~d}, J=6.6 \mathrm{~Hz}, 1 \mathrm{H}), 4.54$ (dd, $J=6.6$, $4.3 \mathrm{~Hz}, 1 \mathrm{H}), 4.48(\mathrm{q}, J=11.7 \mathrm{~Hz}, 1 \mathrm{H}), 3.83(\mathrm{~s}, 3 \mathrm{H}) .{ }^{13} \mathrm{C} \mathrm{NMR}(126 \mathrm{MHz}$, $\left.\mathrm{CDCl}_{3}\right), \delta: 171.9,164.4,159.1,137.6,130.6,130.5,129.2,128.6,128.2$, 128.1, 127.7, 127.4, 127.1, 117.9, 114.2, 94.1, 72.8, 72.7, 55.6, 53.7, 45.3, 29.9. DAD-QTOF: $\mathrm{C}_{26} \mathrm{H}_{25} \mathrm{NO}_{5}[\mathrm{M}+\mathrm{H}]^{+}$calcd.: 417.1702 , found: 417.1702 .

Compound 28: Prepared from compound $27(86 \mathrm{mg}, 0.2 \mathrm{mmol})$ according to the general procedure. Yield: $70 \mathrm{mg}(84 \%)$. $[\alpha]_{D}^{25}=+27.5^{\circ}(c=0.4$ $\mathrm{CH}_{2} \mathrm{Cl}_{2}$, from adduct of $99 \%$ ee). IR $\left(\mathrm{v} / \mathrm{cm}^{-1}\right): 3500(\mathrm{O}-\mathrm{H}), 1731(\mathrm{C}=\mathrm{O}) .{ }^{1} \mathrm{H}$ $\operatorname{NMR}\left(300 \mathrm{MHz}, \mathrm{CDCl}_{3}\right), \delta: 8.06-7.94(\mathrm{~m}, 2 \mathrm{H}), 7.58-7.40(\mathrm{~m}, 2 \mathrm{H}), 7.37(\mathrm{~d}$, $J=8.6 \mathrm{~Hz}, 5 \mathrm{H}), 7.32-7.25(\mathrm{~m}, 2 \mathrm{H}), 7.12-7.06(\mathrm{~m}, 1 \mathrm{H}), 6.93(\mathrm{~d}, J=8.7 \mathrm{~Hz}$, 2H), $5.27(\mathrm{dd}, J=7.5,5.1 \mathrm{~Hz}, 1 \mathrm{H}), 4.66(\mathrm{dd}, J=5.9,5.1 \mathrm{~Hz}, 1 \mathrm{H}), 4.52(\mathrm{~d}$, $J=5.9 \mathrm{~Hz}, 1 \mathrm{H}), 4.35-4.21(\mathrm{~m}, 2 \mathrm{H}), 3.85(\mathrm{~s}, 3 \mathrm{H}), 3.13(\mathrm{~d}, J=7.6 \mathrm{~Hz}, 1 \mathrm{H})$. ${ }^{13} \mathrm{C}$ NMR $\left(75 \mathrm{MHz}, \mathrm{CDCl}_{3}\right), \delta: 172.3,165.1,159.8,137.4,131.4,130.9$, 129.6, 129.2, 128.9, 128.9, 128.0, 128.0, 127.5, 120.2, 114.6, 88.9, 77.9, 74.6, 68.3, 56.0, 47.0, 30.4. DAD-QTOF: $\mathrm{C}_{26} \mathrm{H}_{25} \mathrm{NO}_{5}[\mathrm{M}+\mathrm{H}]^{+}$calcd.: 417.1702, found: 417.1698 .

Preparation of spirocycle 29: To a solution of adduct 18Aa (1 eq., 0.1 $\mathrm{mmol}, 40 \mathrm{mg}$.) in $\mathrm{CH}_{3} \mathrm{CN}(0.3 \mathrm{~mL})$ at room temperature was added $\mathrm{I}_{2}(3$ eq. $0.3 \mathrm{mmol}, 76 \mathrm{mg}$ ) and $\mathrm{NaHCO}_{3}(2$ eq., $0.2 \mathrm{mmol}, 17 \mathrm{mg}$ ). The reaction mixture wasstirred at room temperature overnight, then it wasdiluted with $\mathrm{Et}_{2} \mathrm{O}$ and washed with $\mathrm{H}_{2} \mathrm{O}$. The organic layer was dried over $\mathrm{MgSO}_{4}$ and filtered. The solvent was evaporated under reduced pressure, and the resulting product was crashed with hexane to afford a brown foam. Yield: $44 \mathrm{mg}(86 \%) \cdot[\mathrm{\alpha}]_{\mathrm{D}}{ }^{25}=-11.8^{\circ}\left(c=1.0, \mathrm{CH}_{2} \mathrm{Cl}_{2}\right.$, from adduct of $96 \%$ ee $) .{ }^{1} \mathrm{H}$ $\operatorname{NMR}\left(300 \mathrm{MHz}, \mathrm{CDCl}_{3}\right) \delta: 7.46-7.21(\mathrm{~m}, 9 \mathrm{H}), 7.13(\mathrm{~d}, \mathrm{~J}=7.9 \mathrm{~Hz}, 2 \mathrm{H}), 6.79$ (dd, $J=10.0,2.6 \mathrm{~Hz}, 1 \mathrm{H}), 6.39(\mathrm{dd}, J=10.0,1.4 \mathrm{~Hz}, 1 \mathrm{H}), 6.27-6.16(\mathrm{~m}$, 2H), 5.22 (dd, $J=13.4,7.5 \mathrm{~Hz}, 1 \mathrm{H}$ ), 4.89 (dd, $J=13.4,7.6 \mathrm{~Hz}, 1 \mathrm{H}$ ), 3.90 $3.64(\mathrm{~m}, 2 \mathrm{H}), 3.54(\mathrm{~d}, \mathrm{~J}=4.6 \mathrm{~Hz}, 1 \mathrm{H}) .{ }^{13} \mathrm{C}$ NMR $\left(75 \mathrm{MHz}, \mathrm{CDCl}_{3}\right), \delta: 200.1$, 184.9,175.8, 148.5, 147.7, 136.9, 134.4, 132.6, 132.5, 131.2, 130.6, 129.8 $129.3,129.2,127.5,106.1,78.8,59.4,57.31,43.5,30.5$. UPLC-DAD-
QTOF: $\mathrm{C}_{24} \mathrm{H}_{19} \mathrm{INO}_{4}[\mathrm{M}+\mathrm{H}]^{+}$calcd.: 512.0359 , found: 512.0362 . UPLC DAD-QTOF: $\mathrm{C}_{24} \mathrm{H}_{18} \mathrm{NO}_{4} \mathrm{INa}[\mathrm{M}+\mathrm{Na}]^{+}$calcd.: 534.0178 , found:534.0184.

Preparation of spirocycle 31 : To a solution of adduct $18 \mathrm{Ga}$ (1 eq., 0.13 $\mathrm{mmol}, 55 \mathrm{mg})$ in 1,2-DCE $(1 \mathrm{~mL})$ was added Cu(OTf) 2 (1 eq., $0.13 \mathrm{mmol}$, $47 \mathrm{mg}$ ). The reaction mixture wasstirred at $65^{\circ} \mathrm{C}$ for $3 \mathrm{~h}$. Then the mixture was filtered, rinsed with $\mathrm{CH}_{2} \mathrm{Cl}_{2}$ and concentrated in vacuo to afford a brown foam. $[\mathrm{a}]_{\mathrm{D}}{ }^{25}=-9.5^{\circ}\left(c=1.5, \mathrm{CH}_{2} \mathrm{Cl}_{2}\right.$, from adduct of $98 \%$ ee $)$. Yield: $44 \mathrm{mg}(81 \%)$. ${ }^{1} \mathrm{H}$ NMR $\left(300 \mathrm{MHz}, \mathrm{CDCl}_{3}\right), \delta: 7.41$ (d, J=8.7 Hz, 3H), 6.93 $(\mathrm{d}, J=8.1 \mathrm{~Hz}, 1 \mathrm{H}), 6.82(\mathrm{~d}, J=8.8 \mathrm{~Hz}, 2 \mathrm{H}), 6.65(\mathrm{~s}, 1 \mathrm{H}), 6.56(\mathrm{~d}, J=10.1$ $\mathrm{Hz}, 1 \mathrm{H}), 6.34-6.12(\mathrm{~m}, 2 \mathrm{H}), 5.24(\mathrm{dd}, J=13.2,7.5 \mathrm{~Hz}, 1 \mathrm{H}), 5.02-4.84(\mathrm{~m}$, $1 \mathrm{H}), 3.81(\mathrm{~s}, 3 \mathrm{H}), 3.65(\mathrm{td}, J=7.2,3.5 \mathrm{~Hz}, 1 \mathrm{H}), 3.32(\mathrm{~d}, J=3.4 \mathrm{~Hz}, 1 \mathrm{H}) .{ }^{13} \mathrm{C}$ $\operatorname{NMR}\left(75 \mathrm{MHz}, \mathrm{CDCl}_{3}\right), \delta: 204.2,185.4,173.1,163.3,151.4,151.1,137.4$ 131.0, 130.1, 129.6, 128.9, 127.7, 125.6, 115.1, 94.1, 79.4, 73.8, 56.3, 56.1, 43.1, 30.3. UPLC-DAD-QTOF: $\mathrm{C}_{25} \mathrm{H}_{22} \mathrm{NO}_{5}[\mathrm{M}+\mathrm{H}]^{+}$calcd.: 416.1498 found: 416.1501. UPLC-DAD-QTOF: $\mathrm{C}_{25} \mathrm{H}_{21} \mathrm{NO}_{5} \mathrm{Na}[\mathrm{M}+\mathrm{Na}]^{+}$calcd: 438.1317 , found: 438.1314

Preparation of tricycles 30 and 32: To a solution of the corresponding spirocyclic compound 29 or 31 ( 1 eq., $0.1 \mathrm{mmol}$ ) in dichloromethane $(0.6$ $\mathrm{mL}$ ) was added $\mathrm{Et}_{3} \mathrm{~N}(20$ eq., $2 \mathrm{mmol}$ ) and the reaction mixture was stirred at room temperature for $2 \mathrm{~h}$. The reaction mixture was directly submitted to a non-acidic silica gel column chromatography (eluent hexane/AcOEt $95: 5 \rightarrow 90: 10)$.

Compound 30: Prepared from compound $29(51.1 \mathrm{mg}, 0.1 \mathrm{mmol})$ according to the general procedure. Brown foam, yield: $36.8 \mathrm{mg}(72 \%)$. $[\alpha]_{\mathrm{D}}{ }^{25}=-35.1^{\circ}\left(c=0.3, \mathrm{CH}_{2} \mathrm{Cl}_{2}\right.$, from adduct of $96 \%$ ee $)$. Decomp. $135{ }^{\circ} \mathrm{C}$. ${ }_{1}^{1} \mathrm{H}$ NMR $\left(300 \mathrm{MHz}, \mathrm{CDCl}_{3}\right), \delta: 7.63-7.23(\mathrm{~m}, 10 \mathrm{H}), 6.81$ (dd, $J=10.2,1.6$ $\mathrm{Hz}, 1 \mathrm{H}), 6.36$ (dd, $J=10.2,0.7 \mathrm{~Hz}, 1 \mathrm{H}), 5.00$ (t, $J=11.2 \mathrm{~Hz}, 1 \mathrm{H}), 3.96-3.84$ $(\mathrm{m}, 1 \mathrm{H}), 3.24(\mathrm{~d}, J=9.1 \mathrm{~Hz}, 1 \mathrm{H}), 3.21-3.11(\mathrm{~m}, 1 \mathrm{H}), 2.37(\mathrm{~d}, J=17.7 \mathrm{~Hz}$, $1 \mathrm{H}), 1.94$ (dd, $J=17.8,6.4 \mathrm{~Hz}, 1 \mathrm{H}) .{ }^{13} \mathrm{C}$ NMR $\left(75 \mathrm{MHz}, \mathrm{CDCl}_{3}\right), \delta: 199.9$, 194.2, 176.7, 147.7, 136.8, 134.8, 131.3, 131.2, 130.1, 129.8, 129.2, 128.0, 127.6, 105.5, 94.7, 60.3, 50.7, 47.3, 35.7. UPLC-DAD-QTOF: $\mathrm{C}_{24} \mathrm{H}_{18} \mathrm{NO}_{4} \mathrm{INa}[\mathrm{M}+\mathrm{Na}]^{+}$calcd.:534.0175, found:534.0184.

Compound 32: Prepared from compound $31(41.5 \mathrm{mg}, 0.1 \mathrm{mmol})$ according to the general procedure. Brown solid, yield: $28.7 \mathrm{mg}(69 \%)$ $[\alpha]_{D}^{25}=-9.0^{\circ}\left(c=0.4, \mathrm{CH}_{2} \mathrm{Cl}_{2}\right.$, from adduct of $98 \%$ ee). Decomp. $130{ }^{\circ} \mathrm{C}$. ${ }_{1}^{1} \mathrm{H} \mathrm{NMR}\left(300 \mathrm{MHz}, \mathrm{CDCl}_{3}\right), \delta: 7.62(\mathrm{~d}, \mathrm{~J}=8.9 \mathrm{~Hz}, 2 \mathrm{H}), 7.46-7.24(\mathrm{~m}, 5 \mathrm{H})$, $7.05-6.90(\mathrm{~m}, 3 \mathrm{H}), 6.45(\mathrm{~d}, J=10.2 \mathrm{~Hz}, 1 \mathrm{H}), 6.34(\mathrm{~s}, 1 \mathrm{H}), 4.99$ (t, $J=11.1$ $\mathrm{Hz}, 1 \mathrm{H}), 3.89(\mathrm{~s}, 3 \mathrm{H}), 3.84(\mathrm{~d}, \mathrm{~J}=10.9 \mathrm{~Hz}, 1 \mathrm{H}), 3.21-3.12(\mathrm{~m}, 1 \mathrm{H}), 3.10(\mathrm{~d}$ $J=9.5 \mathrm{~Hz}, 1 \mathrm{H}), 2.61-2.56(\mathrm{~m}, 2 \mathrm{H}) .{ }^{13} \mathrm{C}$ NMR $\left(75 \mathrm{MHz}, \mathrm{CDCl}_{3}\right), \delta: 203.9$, 195.0, 174.9, 163.0, 150.7, 137.0, 130.3, 129.1, 128.2, 128.1, 126.7, 115.4, 96.0, 63.9, 56.2, 51.2, 46.7, 36.8. UPLC-DAD-QTOF: $\mathrm{C}_{25} \mathrm{H}_{22} \mathrm{NO}_{5}\left[\mathrm{M}+\mathrm{H}^{+}\right.$ calcd.: 416.1498 , found: 416.1500

\section{Acknowledgements}

Finantial support was provided by the University of the Basque Country UPV/EHU (UFI QOSYC 11/22), Basque Government (BG Grant No T-628-13), and Ministerio de Economía y Competitividad (MINECO, Grant CTQ2016-78487-C2), Spain, T. C. thanks MINECO and I. I. and O. O. thank BG for fellow ships We also thank SGiker (UPV/EHU) for providing NMR, HRMS, and $\mathrm{X}$-Ray resources.

Keywords: asymmetric catalysis $\cdot$ Brønsted bases $\cdot$ Michael reaction $\cdot$ organocatalysis $\cdot$ alkynyl ketones 
[1] a) Modern Acetylene Chemistry (Eds.: P. J. Stang and F. Diederich), VCH, Weinheim, 1995; b) E. B. Bauer, Synthesis 2012, 44, 1131-1151.

[2] Modern Carbonyl Chemistry (Ed.: J. Otera), Wiley -VCH: New York. 2000

[3] Selected examples: a) (Cy athane diterpenes) P. A. Wender, F. C. Bi, M. A. Brodney, F. Gosselin, Org. Lett. 2001, 3, 2105-2108; b) (Oxcillatoxin D) Y. Nokura, Y. Araki, A. Nakazaki, T. Nishikawa, Org. Lett. 2017, 19, 5992-5995. c) (Azaspiracide-3) N. T. Kenton, D. Adu-Ampratwum, A. A. Okumu, Z. Zhang, Y. Chen, S. Nguyen, J. Xu, Y. Ding, P. McCarron, J. Kilcoyne, F. A. L. Wilkins, C. O. Miles, C. J. Forsyth, Angew. Chem 2018, 130, 818-821; Angew. Chem Int. Ed. 2018, 57, 805-809.

[4] For reviews, see: a) R. Salvio, M. Moliterno, M. Bella, Asian J. Org. Chem 2014, 3, 340351; b) A. Fraile, A. Parra, M. Tortosa, J. Alemán Tetrahedron 2014, 70, 9145-9173; c) R. E. Whittaker, A. Dermenci, G. Dong Synthesis 2016, 48, 161-183.

[5] a) K. Fujii, K. Maki, M. Kanai, M. Shibasaki, Org. Lett. 2003, 5, 733-736; b) K. Maki, R. Moloki, K. Fuji, M. Kanai, T. Kobay ashi, S. Tamura, M. Shibasaki, J. Am Chem Soc. 2005, 127, 17111-17117; c) S. L. Shi, M. Kanai, M. Shibasaki, Angew. Chem 2012, 124, 3998-4001; Angew. Chem Int. Ed. 2012, 51, 3932-3935; d) B. M. Trost, A. Fetters, B. T. Shireman, J. Am Chem Soc. 2004, 126, 2660-2661; e) B. M. Trost, M. U. Fredericksen, J. P. N. Papillon, P. E. Harrington, S. Shin, B. T. Shireman, J. Am Chem Soc. 2005, 127, 3666-3667; f) F. Silva, M. Sawicki, V. Gouverner, Org. Lett. 2006, 8, 5417-5419; g) G. Kang, J. Jiang, H. Liu, H. Wu, J. Braz. Chem Soc. 2012, 23, 5-10; h) F. Silva, M. Reiter, R. Mills-Webb, M. Sawicki, D. Klär, N. Bensel, A. Wagner, V. Gouv erneur, J. Org. Chem 2006, 71, 8390-8394.

[6] a) B. M. Trost, C. I. Hung, J. Am Chem Soc. 2015, 137, 15940-15946; b) S.-L. Shi, X.F Wei, Y. Shimizu, M. Kanai, J. Am Chem Soc. 2012, 134, 17019-17022.

[7] Domino cy clisation: a) h) D. B. Ramachary, C. Venkaiah, P. M. Krishna, Chem Commun. 2012, 48, 2252-2254; b) D. B. Ramachary, C. Venkaiah R. Nadhav achary, Org. Lett. 2013, 15, 3042-3045.

[8] Selected reviews on Brønsted base-promoted asy mmetric reactions: a) S.-K. Tian, Y. Chen, J. Hang, L. Tang, P. McDaid, L. Deng, Acc. Chem Res. 2004, 37, 621-631; b) C. Palomo, M. Oiarbide, R. López, Chem. Soc. Rev. 2009, 38,632-653; c) A. Ting, J. M. Goss, N. T. McDougal, S. E. Schaus, Top. Curr. Chem 2010, 291, 145-200; d) R. P. Singh, L. Deng in Asymmetric Organocatalysis 2: Brønsted Base and Acid Catalysts, and Additional Topics (Ed.: K. Maruoka) Thieme, Stuttgart, 2012, pp 41118; e) H. B. Jang, J. S. Oh, C. E. Song in ref 23d, pp 119-16.

[9] a) D. A. Alonso, S. Kitagaki, N. Utsumi, C. F. Barbas, III Angew. Chem, 2008, 120, 4664-4667; Angew. Chem, Int. Ed. 2008, 47, 4588-4591; b) J. Guang, S. Rout, M. Bihani, A. J. Larson, H. D. Arman, J. C.-G. Zhao Org. Lett. 2016, 18, 2648-2651.
[10] W. Liu, L. Zou, B. Fu, X. Wang, K. Wang, Z. Sun, F. Peng, W. Wang, Z. Shao, J. Org. Chem 2016, 81, 8296-8305.

[11] I. Iriarte, O. Olaizola, S. Vera, I. Ganboa, M. Oiarbide, C. Palomo, Angew. Chem 2017, 129, 8986-8990; Angew. Chem Int. Ed. 2017, 56, 88608864 .

[12] a) L. Dai, S.-X. Wang, F.-E. Chen, Adv. Synth. Catal. 2010, 352, $2137-$ 2141; b) W. Yang, D.-M. Du, Org. Lett. 2010, 12, 5450-5453. For pioneering work on squaramides as cataly sts, see: c) J. P. Malerich, K Hagihara, V. R. Rawal, J. Am Chem Soc. 2008, 130, 14416-14417; d) Y. Zhu, J. P. Malerich, V. H. Rawal, Angew. Chem 2010, 122, 157-160; Angew. Chem Int. Ed. 2010, 49, 153-156. For reviews, see: e) R. I. Storer, C. Aciro, L. H. Jones, Chem Soc. Rev. 2011, 40, 2330-2346; f) J. Alemán, A. Parra, H. Jiang, K. A. Jørgensen, Chem Eur. J. 2011, 17, 6890-6899; g) P. Chauahn, S. Mahahan, U. Kay a, D. Hack, D. Enders, Adv. Synth. Catal. 2015, 357, 253-281.

[13] See the Supporting Inf ormation for details.

[14] H. Jiang, M. W. Paixão, D. Monge, K. A. Jørgensen J. Am Chem Soc. 2010, 132, 2775-2783.

[15] I. Olaizola; T. E. Campano, I. Iriarte, S. Vera, A. Mielgo, J. M. García, J. M. Odriozola, M. Oiarbide, C. Palomo Chem Eur. J. 2018, 24, 3893-3901.

[16] A. Odriozola, M. Oiarbide, C. Palomo Chem Eur. J. 2017, 23, 1275812762.

[17] CCDC-1858603 (compound 15Ab) and 1858826 (compound 22Ae) contain the supplementary crystallographic data for this paper. These data can be obtained from the Cambridge Cry stallographic Data Center via www.ccdc.cam.ac.uk/data_request/cif. See the Supporting Inf ormation for details.

[18] a) N. T. Anh, O. Eisenstein, Nouv. J. Chim 1977, 1, 61-70.; b) T. Nakata, T. Tanaka, T. Oishi, Tetrahedron Lett. 1983, 24, 2653-2656.

[19] T. Tokuy ama, K. Shimada, M. Uemura, Tetrahedron Lett. 1982, 23, 2121-2124.

[20] C. Matt, A. Wagner, C. Mioskowski, J. Org. Chem 1997, 62, 234-235.

[21] X. Zhang, R. C. Larock, J. Am Chem Soc. 2005, 127, 12230-12231.

[22] A. K. Clarke, J. T. R. Liddon, J. D. Cuthbertson, R. J. K. Tay lor, N. P. Unsworth Org. Biomol. Chem 2017, 15, 233-245.

[23] A E. Mevers, J. Sauri, Y. Liu, A. Moser, T. R. Ramadhar, M. Varlan, R. T. Williamson, G. E. Martin, J. Clardy, J. Am Chem Soc. 2016, 138, 12324-12327.

[24] Racemic sy nthesis of homodimericin A: J. Huang, Y. Gu, K. Guo, L. Zhu Y. Lan, J. Gong, Z. Yang, Angew. Chem 2017, 129, 7994-7997; Angew. Chem Int. Ed. 2017, 56, 7890-7894. 
Entry for the Table of Contents (Please choose one layout)

\section{FULL PAPER}

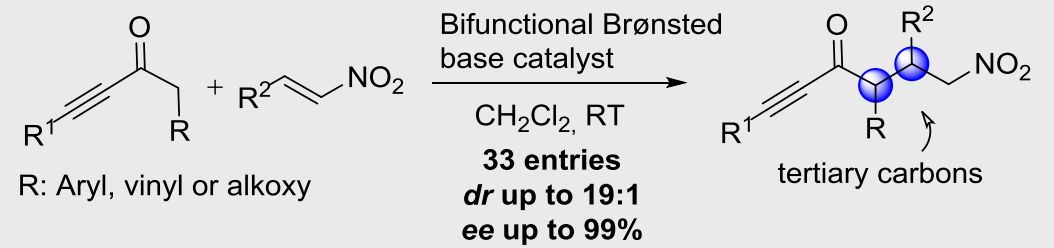

Donor ynones: under very mild conditions linear ynones with no additional EWG at $\mathrm{C} \alpha$ get activated by tertiary amine/squaramide chiral catalysts and react $w$ ith nitroolefins in a highly diastereo- and enantioselective fashion. This way, an easy entry to branched alkyl alkynyl ketones $w$ ith two contiguous stereocenters and derivatives thereof is provided.
T. E. Campano, I. Iriarte, O. Olaizola, J. Etxabe, A. Mielgo, I. Ganboa, J. M.

Odriozola, J. M. García, M. Oiarbide*, C. Palomo*

Page No. - Page No.

Enantioselective Addition of Alkynyl Ketones to Nitroolefins Assisted by Brønsted Base/H-Bonding Catalysis. 